\title{
THE WEBSITE CONTENT AS POSITIONING STRATEGY OF THE UNIVERSITY IN INDONESIA
}

\author{
Amida Yusriana \\ Universitas Diponegoro' Indonesia \\ Email: amidayusriana88@gmail.com \\ Mutia Rahmi Pratiwi \\ Universitas Dian Nuswantoro Semarang Indonesia \\ mutia.rahmi@dsn.dinus.ac.id \\ Lisa Mardiana \\ Universitas Dian Nuswantoro Semarang Indonesia \\ lisa.mardiana@dsn.dinus.ac.id
}

\begin{abstract}
University of Indonesia is granted as the number one campus based on the Webometrics rank. It cannot be separated from the way University of Indonesia in building a strategic content for its website thus can fulfill the four points score indexes of webometrics such as Presence, Impact, Openness, and Excellence. Never theless the way the website serves the menu and information can build the right point of the scores. At the same time, Dian Nuswantoro University is granted as the 31st rank for the Webometrics index. Hence, by analyzing the website content of University of Indonesia, later it can be a guideline for Dian Nuswantoro University in developing a better content. This research uses the Positioning Strategy Theory. This is a descriptive quantitative research with a content analysis method. The results shows that the University of Indonesia uses the functional concept positioning strategy as its website content strategy.
\end{abstract}

Keyword: Website Content; Positioning Strategy; University

ACCEPTED : August $4^{\text {th }}, 2020$ REVIEWED: January $15^{\text {th }}, 2021$ PUBLISHED: January $28^{\text {th }}, 2021$ 


\section{Introduction}

University of Indonesia is a modern, comprehensive, open, multicultural, and humanist with broader scope of subjects university. In the mean time, University of Indonesia simultaneously tries to be a research university or a prominent academic institution in the world. As a research university, the efforts to reach the highest achievement in the field of research's finding, development and knowledge diffusion regionaly and globaly are always pushed. Meanwhile, University of Indonesia deepen the comitment in the efforts of academic development and research activity by the subjects it has.

The vangard of University of Indonesia was back in 1894 and University of Indonesia is the representation of academic institution with the oldest history in the Asia. University of Indonesia has more than 400.000 alumnis, it continuosly serves the important role in the national and world level. The recent mission of University of Indonesia is to be a high quality academic institution, world standard research and keeping the international standard journal.

University of Indonesia actively develops the global cooperation to lots of famous universities in the world. Besides, University of Indonesia recently strengthen its cooperation with several academic and research associations, such as APRU (Association of Pacific Rim Universities) by the role as the Board of Director, AUN (ASEAN University Network), and ASAIHL (Association of South East Asia Institution of Higher Learning).

Geographically, University of Indonesia is located in two areas, Salemba and Depok. The majority of faculty are in the Depok by the 320 acre and green atmosphere campus because only $25 \%$ of the area are used as the academic, research and student center. $75 \%$ of the area are the green area in the form of city forest (http://www.ui.ac.id).

The vision of University of Indonesia is: "Becoming the center of knowledge, technology, and best in the cultural and rivalry value, by the efforts of educating the nation's life to improve the society's prosperity, thus contributing in developing the Indonesia society and the world citizen. 
Meanwhile there is a little bit difference between what it stated on the website and one in the Strategic Planning sheet (3-4: 2017), the vision is: "The Realization of Universitas Indonesia as a state owned Higher Education Legal Entity that is independent and excellent and is able to solve problems and challenges nationally as well as globally, towards excellence in Southeast Asia."

The missions of University of Indonesia are: 1) Provide a broad and fair access, and as well as qualified education and teaching; 2) Implement Tridharma activities which are qualified and relevant to national and global challenges; 3) Create graduates who have high intellectuality, noble character, and are able to compete globally; and 4) Create an academic climate that can support the realization of UI vision.

The vision and missions are made in accordance to the main roots of all the foundation. The foundation usually known as philosophy. The University of Indonesia's Educational Philosophy are: 1) In accordance to 1945 Constitution of the Republic of Indonesia Preambule: "to develop the nation's intellectual life", University of Indonesia strives to equip students with the nature of global competitiveness, intelligence and skilled, based on Indonesian characters; 2) Prepare students to contribute in the advancement of nation's prosperity; 3) Enable students to explore and use their full potential to become an ethical intellectual, cultured, competent, and able to enter the workforce or to create jobs and develop themselves to be professionals; 4) Support the students to study and work across disciplines to foster a diverse and individual learning experience; 5) Encourage students to become individuals who will grow and be mature emotionally, intelectually, physically, and socially.

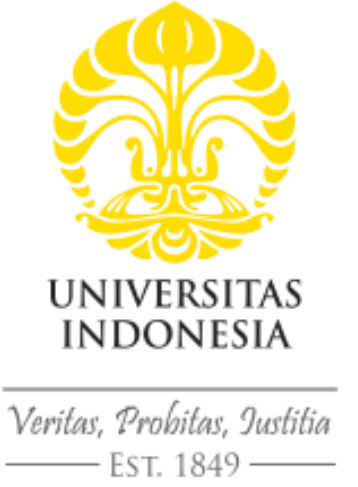

Image 1. The logo of University of Indonesia source: www.ui.ac.id 
As one of the oldest university in Indonesia, based on the factsheet of University of Indonesia periode 2018-2019 (1-5:2018), it offers 62 undergraduate programs, 68 master programs, and 37 doctorate programs. The university consists of 14 faculties, 2 graduate schools and 1 vocational program that offers a wide range of vocational studies. It consists of Faculty of Medicine, Faculty of Dentistry, Faculty of Public Health, Faculty of Nursing, Faculty of Pharmacy, Faculty of Mathematics and Natural Sciences, Faculty of Engineering, Faculty of Computer Science, Faculty of Law, Faculty of Economics and Business, Faculty of Humanities, Faculty of Psychology, Faculty of Social and Political Sciences, Faculty of Administrative Sciences, Graduate School of Environmental Studies, Graduate School of Strategic and Global Studies and Vocational Programs.

All of those information about University of Indonesia can be obtained by a simple click into their website on www.ui.ac.id. The website is bilingual. People can accessed it in Indonesia language and for the foreign students or stakeholder can get the information easily by clicking the english version.

Website as the main portal of information for certain thing is the form of life style changing. Nowadays, everything are so depend on the digital world. The website of University of Indonesia can be the sample of this phenomena. Thus, alots of universities have been competing in serving a comprehensive and up to date website content. The development of website then become the main basis of university ranking or oftenly called as the Webometrics.

The World University Rank by Webometrics aims to improve the publication and the convenience to access a scientific journal of university. Webometrics was launched in 2014 by scoring the website content, visibility and the impact of a web. The renewal of the ranking is conducted every January and July. Up to now, webometrics becomes the trusted source for all the universities in the world (webometrics.info/en). The main indicator for webometrics are Presence, Impact, Openness, dan Excellence. The compositions of scoring are Presence: $5 \%$, Impact: 50\%, Openness: 10\%, Excellence: 35\% (https://unycommunity.com). 
University of Indonesia by the July version of Webometrics rank is the number one. It can be seen by this table:

Table 1. The ranking position of University of Indonesia July 2018 Source: webometrics.info/en.

\begin{tabular}{|c|c|c|c|c|c|c|c|}
\hline RANKING & $\begin{array}{l}\text { WORLD } \\
\text { RANK }\end{array}$ & UNIVERSITY & DET. & $\begin{array}{l}\text { PRESENCE } \\
\text { RANK* }\end{array}$ & $\begin{array}{l}\text { IMPACT } \\
\text { RANK* }\end{array}$ & $\begin{array}{l}\text { OPENNESS } \\
\text { RANK* }\end{array}$ & $\begin{array}{l}\text { EXCELLENCE } \\
\text { RANK* }^{\star}\end{array}$ \\
\hline 1 & 837 & $\begin{array}{l}\text { Universitas } \\
\text { Indonesia }\end{array}$ & 말 & 237 & 436 & 1519 & 1563 \\
\hline 2 & 856 & $\begin{array}{l}\text { Universitas Gadjah } \\
\text { Mada }\end{array}$ & 필 & 170 & 459 & 641 & 1841 \\
\hline 3 & 1126 & $\begin{array}{l}\text { Institut Teknologi } \\
\text { Bandung / Institute } \\
\text { of Technology } \\
\text { Bandung }\end{array}$ & 플 & 465 & 984 & 1480 & 1637 \\
\hline
\end{tabular}

As for the latest ranking, University of Indonesia is the number one in indonesia. Never theless the position of University of Indonesia in the world rank is the number 837 . The detail of the score are for the presence rank, University of Indonesia obtain as 237th, the impact rank that correlate to its publication is 436th, the openness of information can be seen as 1519th while the excellence rank is the the lowest as 1563rd. Meanwhile the Gadjah Mada University is in number two and in the world is number 856. Those show that University of Indonesia is the best in presence rank rather than other score. Eventhough, Gadjah Mada University shows better performance by number 170 .

Presecence Rank, Openness Rank dan Excellence Rank earn similiar scoring index by $50 \%$ of the alocation, impact factor is the highest one to hold the $50 \%$ of the scoring. It counted by the external link of the third party. The number of link is related to international standard, academic performance, and the usage level of the sites's service (https://edukasi.kompas.com).

By positioned as the highest rank in the latest Webometrics, shows the ability of University of Indonesia in managing the content. A good contents will always pay attention to the important indicators such as 
openess, presence and excellence by giving informative content and give impact toward the users.

By learning from this situation, another universities need to correct their way in managing their websites. Such as Dian Nuswantoro University. Based on the collected information from the Webometrics website, Dian Nuswantoro University is in 31st rank. Here is the table:

Table 2. Dian Nuswantoro University Webometrics Rank in July 2018 Source: webometrics.info/en.

\begin{tabular}{|c|c|c|c|c|c|c|c|}
\hline 29 & 3617 & $\begin{array}{l}\text { Universitas Islam } \\
\text { Indonesia }\end{array}$ & च & 568 & 828 & 2273 & 5974 \\
\hline 30 & 3649 & $\begin{array}{l}\text { Universitas } \\
\text { Narotama UNNAR } \\
\text { Surabaya }\end{array}$ & (2) & 2176 & 506 & 4991 & 5974 \\
\hline 31 & 3691 & $\begin{array}{l}\text { Universitas Dian } \\
\text { Nuswantoro }\end{array}$ & 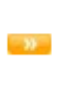 & 1085 & 3847 & 4071 & 4621 \\
\hline
\end{tabular}

Based on the above table, the rank of Dian Nuswantoro University is 31 st in Indonesia. While in the world rank is number 3691. The best performance of Dian Nuswantoro University is on the presence as it shown above by 1085, it is far better than Narotama UNNAR Surabaya University as the main rival. Eventhough, as for another ranks, the Dian Nuswantoro University has not show good performances by becoming number 3847, 4071 and 4621.

According to those ranks, it can be concluded that Dian Nuswantoro University is not good in managing the website's presence. This condition is contarts to the fact that this university's main point is the information technology. It is famous by its pioneer in the field of information technology. The information technology major is the magnet of this university to get new college students.

It relates to its history. Back in 1986, Edi Noersasongko as the founder of later called by Dian Nuswantoro University held a computer course named IMKA, it is located in Semarang. By his will in developing a new market chance and his endurance in facing the problems, IMKA has grown and spread its influence towards some big cities in Java Island 
such as Semarang, Surakarta, Yogyakarta, Surabaya, Bandung and Jakarta. Besides, because of its academic quality, in 1989, IMKA is choosen as the lead of Computer Sub Consortium, supervisor and examiner of Computer Academy National Exam.

In September 30th 1993, IMKA got the NCC (The National Computing Centre) London accreditation. By this meaningful accreditation, IMKA has the authority to lecture and publish the International Certificate. The computer masters of IMKA and some academicians then held the Dian Nuswantoro Foundation. This foundation got the authority in helding the academy of Computer and Information Management that then called as the AMIK Dian Nuswantoro. The first lecturing class is consists of 54 students. By the belief that higher education should be developed into a system for the national's need letting the foundation to change the academy system into higher education (sekolah tinggi).

In March 3rd 1994, AMIK Dian Nuswantoro has changed into Sekolah Tinggi Manajemen Informatika dan Komputer (STMIK) Dian Nuswantoro. Then in 2001, STMIK Dian Nuswantoro had more than 9000 students and has graduated 1106 alumni. Later in 2000, the Information Management and Information Technology were accredited. To complete it, the new study of Computerized Accountant were opened.

The Dian Nuswantoro Foundation opened STIE, a higher education for economy. By the majors were: Managemen, Accounting and Taxation. The students were 187 for 1999/2000 and doubled up to 359 in $2000 / 2001$ academic year. Once again, realized by the importance of foreign languages in the human's life, later on March 15 2000, the Dian Nuswantoro Foundation opened the Sekolah Tinggi Bahasa Asing (STBA) Dian Nuswantoro. The majors were: English Literatur, English, Japanese and Mandarin. STBA Dian Nuswantoro became the thid higher education that held the Mandarin class, other than University of Indonesia and Dharma Persada University. In academic year of 2000/2001, there were 466 students accepted in STBA. To add it, the Dian Nuswantoro Foundation in cooperation with doctors and health experts unite as the Lintang Nuswantoro Foundation. It then opened the Sekolah Tinggi Kesehatan (STKES) Lintang Nuswantoro as one of the pioneer of school of health in Indonesia. The majors were: Public Health 
and Hiperkes. To improve the efficiency and works of the management, then in the academic year of 2001/2002 those four higher education systems were combined into Dian Nuswantoro University.

Thus, Dian Nuswantoro University has five faculties: Computer Faculty (former STMIK Dian Nuswatoro), Economic Faculty (former STIE Dian Nuswantoro), Language and Literature Faculty (former STBA Dian Nuswantoro), Public Health Faculty (former STKES Lintang Nuswantoro) and Engineering Faculty. Dian Nuswantoro University kept its hardwork and achievement. Then in 2002, Dian Nuswantoro added 2 more majors, there were the Industial Engineering below of the Engineering Faculty and theMasterprogram for Computer Science (http://id.dinus.ac.id).

To strengthen the working ethic of Dian Nuswantoro University, the vision is to become the main choice university in the field of academic and entrepreneur. While the missions are to perform a qualified higher education, to develop the creativity and innovation of the academicians for the beneficial of society, government and the enterprenership.

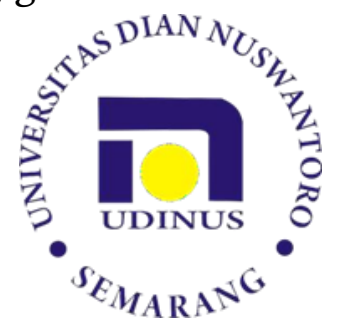

Image 2. The logo of Dian Nuswantoro University

Source: www.dinus.ac.id

The logo of Dian Nuswantoro University is a combination between the $\mathrm{D}$ and $\mathrm{N}$ as the abbreviation of Dian Nuswantoro. The $\mathrm{N}$ alphabet is bending as the symbol of seeking for protection of God. Meanwhile the gold circle represents the image of togheterness, self determination and the dynamic of life. It means that by the togheterness value and self determination, all the family of Dian Nuswantoro University will always be ready to move forward to enrich the life of the nation. The motto of this university is "For A Better Future". While the slogan is Dumununging Ingsun Angrakso Nagoro Nuswantoro. 


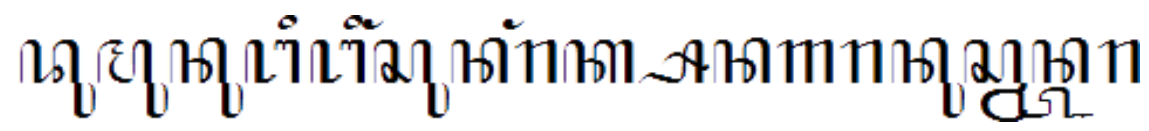

Information Technology of Dian Nuswantoro University is claimed as the best in town. This situation is proven by the signing of memorandum of understanding between Dian Nuswantoro University and UIN Walisongo last September. The Rector and The Dean of UIN Walisongo stated that Dian Nuswantoro was the best and right place to learn about Information Technology (http://www.dinus.ac.id).

The expertise in information technology is strengthen by the international achievement of the student. Diky Arga Anggara, the Information Technology student got the chance to represent Indonesia joined in Mozfest in London in last 2016. In this chance, diky introduced his work in cooperation with Dinus Open Source Community (Doscomm) the name is software TeaLinux Operating System. Reaching the international scale was not easy way for him. Diky had to compete more than 900 proposals from various backgrounds and topic. The result of the Mozfest its Diky becomes one of the mozzilian or known as Firefox Student Ambassador and mozzila tech speaker (https://atdikbudlondon.com).

The fact of Dian Nuswantoro University's achievement in the field of IT also strengthen by Leprid (Lembaga Prestasi Indonesia Dunia). It annouced Dian Nuswantoro University as a creative university in conserving the art and cultural heritage based on technology (E-Gamelan, E- Macapat, Madhang Id, Kandhani.com dan Benthik Vr). Dian Nuswantoro University combine the traditional culture and the technology into something advance (https://daerah.sindonews.com).

According to those data, Dian Nuswantoro University is famous by its skill in the Information Technology world. Hence it should be able to fulfill the presence point in the webometrics. Meanwhile University of Indonesia is famous as the stated university with different desired faculties such as Faculty of Medicine, Faculty of Economy and Faculty of Education. (http://wartakota.tribunnews.com).

In accordance to that statement, the research result of tirto.id showed that in the last three years, the famous majors in University of Indonesia 
is English Literature and Medicine. The applicants for the English Literature in 2017 are 1.859 people for 24 quota. This ratio represents the 1 to 78. While for the Medicine major, the SBMPTN 2017 gave 3,2 percent of quota for the applicants (https://tirto.id/sbmptn-2018).

This fact explains that University of Indonesia is not famous by the information technology but the situation is vise versa. University of Indonesia gets the highest rank in webometrics, nevertheless Dian Nuswantoro University is in the 31st rank. Thus, the research problem is to understand how is the website contents strategy of University of Indonesia? Then to answer it, the aim of this research is to understand how the website contents strategy of University of Indonesia is.

\section{Research Method}

The Webometrics, the initial purpose of this ranking system is to promote the web publication. However web indicators are very useful for ranking purposes too as they are not based on number of visits or page design but on the global performance and visibility of the universities (Rasimin, 2018)

As other rankings focused only on a few relevant aspects, specially research results, web indicators based ranking reflects better the whole picture, as many other activities of professors and researchers are showed by their web presence.

The Web covers not only only formal (e-journals, repositories) but also informal scholarly communication. Web publication is cheaper, maintaining the high standards of quality of peer review processes. It could also reach much larger potential audiences, offering access to scientific knowledge to researchers and institutions located in developing countries and also to third parties (economic, industrial, political or cultural stakeholders) in their own community.

The Webometrics ranking has a larger coverage than other similar rankings (see table below). The ranking is not only focused on research results but also in other indicators which may reflect better the global quality of the scholar and research institutions worldwide.

Webometrics intends to motivate both institutions and scholars to have a web presence that reflect accurately their activities. If the web 
performance of an institution is below the expected position according to their academic excellence, university authorities should reconsider their web policy, promoting substantial increases of the volume and quality of their electronic publications.

Candidate students should use additional criteria if they are trying to choose university. webometrics Ranking correlates well with quality of education provided and academic prestige, but other non-academic variables need to be taken into account (Aguilo, 2010: 85).

Website content, website itself is an online sytem that cannot be separated from modern people's lifestyle. The changing in the lifestyle has lead everyone to depend their life on the online information that a website serves. Thus, every company, university, insitution, cafe, store, shop, restaurant or many services should employs the website with a very comprehensive contents. In making a content and presents it to user is not an easy task. A company needs one person at least that in charge to develop and manage the contents of the company so it will not go old.

Content is collection of information which is either created or acquired from the given source. So, content may be considered as a set and there is need to do some functional work on the content so that a beautiful website will be published (Srivastav, 2016:57). (1) A strategy of Web Content Management may be as follows: (2) Identifying Content

Strategy of positioning, the Positioning Strategy (Hasan, 2014: 400 402 ) is the way to create distinguished difference in the user's minds, thus it can produce certain image of the brand or leading brand than the competitors.

The Positioning Strategy needs to be able to show; (1) How the product mix can be placed in the market (2) The Positioning Strategy filled with the various combination of marketing mix that used to create the positioning in the user's minds, (3) The development of positioning should be along to the main decision of marketing program

This research uses the descriptive qualitative approach. It is chosen because of the purpose of the research that tries to understand how the conducted content strategy by University of Indonesia is. Strategy is part of the descriptive approach and only can be understood by using the operationale model of the qualitative approach. Content Analysis becomes the right one to accomodate this kind of research. Generaly, 
Content Analysis can be defined as a technique of research to know the content's characters and conclude the content inferency (Eriyanto, 2011:15). Barelson (1952:18), Content Analysis is a research tehnique that conducted objectively, systematically and quantitative descriptive of the manifest communication. Meanwhile Holsti (1969:14) said that Content Analysis is a research technique to make inferencies objectively ann identify the message's characters systematically.

\section{Results and Discussion}

This research will be conducted according to the steps of the quantitative content analysis method: (1) Formulating the purpose of the analysis, the main purpose of the analysis is to find the content development strategy by the University of Indonesia. The process is started by putting the University of Indonesia's website as the primary data of this research. The webometrics renews its ranking twice in a year in the January 2018 and July 2018.

Concepting and operating, the data by grouping some amounts of data based on the operational concept. Before doing it, the main purpose of the research should be understood. The coding sheet is by inserting the operational value to the coding sheet In determining the coding sheet, operational value are breakdowned according to the used theory. In this research, Positioning Strategy will be used as the theory. By leaning the every aspects of the strategy, it determined that the operational value will be as follow: (1) functional concept, (2) symbolic concept, (3) experience concept, (4) health concept or ecology, (5) price-quality concept, (6) user concept, (7) atribute concept, (8) application positioning: positining based on application, (9) benefit positioning, (10) competitor positioning.

The coding is by coding all the materials to the formulated coding sheet, consists of three steps such as open coding, axial coding and selective coding. The Selective coding will be based on the operational values (Eriyanto, 2011:173 - 189).

\section{The Website Analysis}

The data analysis unit is the website of University of Indonesia. It can be accessed in www.ui.ac.id by various search engine. The first click 
will lead the user to the interface, a homepage that consists of several buttons.

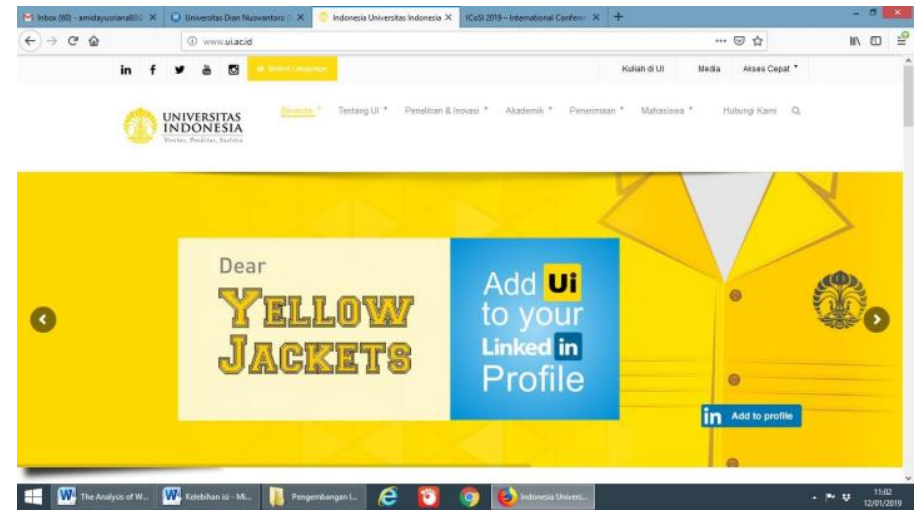

Image 4. The Main Home Interface of University of Indonesia's Website Source: www.ui.ac.id

The next step is by grouping the content of the website. There are two categories of contents, they are the menu and news content. The menu consists of 77 points: menu and sub menu. While the news are from the November 2018 to January 2019. The determination of this range of time is based on the main aim of the research. This is part of a bigger research that tries to compare between University of Indonesia and Dian Nuswantoro University. Dian Nuswantoro University has weakness in repository of the news. The last news can be accessed in November 29th 2018. Meanwhile in University of Indonesia are richer in the file repository. To be able to focus on the main purpose, so the research will be done for the november 29th 2018 to January 28th 2019.

After conducting it, the next step is by organizing the data of menus and the title of the news and each will be grouped by the certain positioning strategy that explored previously. The result shows:

Table 3. The Working Table of Positioning Strategy for the Menu

\begin{tabular}{ll}
\hline Functional Concept & $\mathbf{: 1 4}$ \\
\hline Symbolic & $: 1$ \\
Experience & $: 23$ \\
Health/Environment & $: 0$ \\
Price-Quality & $: 1$ \\
User & $: 1$
\end{tabular}




$\begin{array}{ll}\text { Atribute } & : 23 \\ \text { Application Positioning } & : 0 \\ \text { Benefit Positioning } & : 0 \\ \text { Competitor Positioning } & : 0\end{array}$

According to the operational table, it presents that the direction of the menu and sub menu shown that in the University of Indonesia's website taking the positioning that prioritize Experience and Atribute. Experience Concept is the position of product designed by strengthening the experience of user in using the product to fill the needs. While the Atribute The position is designed by strengthening one or several attributes - features - customer benefits that is related to the benefit for the user. The attributes are choosen based on these: (1) Level of importance: it means that the attributes is very valuable to the customer, (2) Level of distinctiveness: it means that the attributes is unique that none offers, (3) Level of superiority: the attributes are superior than others, (4) Communicability: the attributes can be communicated in clear and simple ways, thus the user's understand, (5) Preemptive, the attributes are hard to fake, (6) Affordability, the users willing to pay the uniqueness of the product, (7) Profitability, the company can earn the profit

Whereas the second most is the Functional Concept. Nevertheless, the positioning strategy should be combined with positioning strategy of the news. The total are 82 news consist of various topics. Here is the working table as the result

Table 4. The Working Table of Positioning Strategy for The News

\begin{tabular}{ll}
\hline Functional Concept & $\mathbf{: 2 7}$ \\
\hline Symbolic & $: 34$ \\
Experience & $: 2$ \\
Health/Environment & $: 29$ \\
Price-Quality & $: 0$ \\
User & $: 16$ \\
Atribute & $: 2$ \\
Application Positioning & $: 0$ \\
Benefit Positioning & $: 0$
\end{tabular}


In the above table, the Symbolic Positioning plays the biggest part, followed by the Health/Environment also Functional and Competitor Positioning. In this case, every news can employ more that one positioning. For example one news can fulfilled the Competitor Positioning and at the same time aims the Functional Concept. The last result of the positioning can be assumed by the combined amounts of menu and news. Here is the combined table of both:

Table 5. The Combination of Both Working Tables

\begin{tabular}{ll}
\hline Functional Concept & $: \mathbf{4 1}$ \\
\hline Symbolic & $: 35$ \\
Experience & $: 25$ \\
Health/Environment & $: 29$ \\
Price-Quality & $: 1$ \\
User & $: 17$ \\
Atribute & $: 25$ \\
Application Positioning & $: 0$ \\
Benefit Positioning & $: 0$ \\
Competitor Positioning & $: 27$ \\
\hline
\end{tabular}

The above table shows that by combining the menu and news, University of Indonesia's website is in fact using the Functional concept as its way of presenting the website. Functional concept is conducted by strengthening the function of the product. In the case of the university, the content is more into the university function as an academic institution, its function in innovation, analyzing the situation of society and giving contribution for the development of knowledge.

\section{Conclusion}

Dian Nuswantoro University is well known by its information technology major. Despite of being a private university, this research tries to find the best website content strategy for The Dian Nuswantoro University by comparing the University of Indonesia and Dian 
Nuswantoro University. It is based on the ranking system of Webometrics last July 2018.

Employing the quantitative content strategy, the website of University of Indonesia are breakdown into two contents, the menu and the news. The result shows that University of Indonesia uses the Functional Concept as its positioning strategy. Thus, most of the contents are organized by determining the function of this university as an academic institution.

\section{Bibliography}

Aguillo, IF; Bar-Ilan, J; Levene, M. Ortega, JL (2010). Comparing university rankings. Scientometrics, 85:243-256

Anonim.(2018). UIN Akui IT Udinus Yang Terbaik. In http://www.dinus.ac.id/getnews/1574/UIN-AKUI-ITUDINUS-YANG- TERBAIK accessed in December 26th 2018 at $01.18 \mathrm{pm}$

Anonim. (2018). Universitas Terbaik di Indonesia Versi Webometrics Juli 2018. In https://unycommunity.com/universitas-terbaik-diindonesia-versi- webometrics-juli-2018/ accessed in September 23rd 2018 at $12.46 \mathrm{pm}$

Antoni, Ahmad. 2(2018). Ciptakan E-Gamelan Udinus Jadi Kampus Kreatif Berbasis Teknologi. In

https://daerah.sindonews.com/read/1356837/22/ciptakan-e-

gamelan-udinus- jadi-kampus-kreatif-berbasis-teknologi1542899459 accessed in December 26th 2018 at $4.19 \mathrm{pm}$

Barry, T. E., \& Howard, D. J. (1990). A review and critique of the hierarchy of effects in advertising. International Journal of Advertising, 9(2), 121- 135.

Damanik, Caroline. (2013). Jangan Salah Kaprah Soal Ranking Kampus di Dunia. In https://edukasi.kompas.com/read/2013/02/28/08100027/jang an.salah.kaprah .soal.ranking.kampus.di.dunia accessed in $23 \mathrm{rd}$ September 2018 at $1.58 \mathrm{pm}$ 
Eriyanto. (2011). Analisis Isi: Pengantar Metodologi Untuk Penelitian Ilmu Komunikasi dan Ilmu-Ilmu Sosial Lainnya. Jakarta: Prenadamedia Group.

Firdaus, Fitra.(2018). SBMPTN 2018 Cek Prodi Paling Favorit di UI Dalam 3 Tahun terakhir. In https://tirto.id/sbmptn-2018-cekprodi-paling-favorit- di-ui-dalam-3-tahun-terakhir-cHho accessed in December 27th 2018 at 8.39am

Hasan, Ali. (2014). Marketing dan Kasus-Kasus Pilihan. Jakarta: PT. Buku Seru.

Ngazis, Amal Nur \& Dwi Royanto. (2016). Programmer Udinus Tampil Memukau di

London. https://atdikbudlondon.com/2016/11/04/programer- udinustampil-memukau-di-london/ accessed in December 26th at 01.30 pm

Putri, Anggri Lianda. (2018). Tiga Fakultas Favorit di Universitas Indonesia.

In

http://wartakota.tribunnews.com/2018/05/08/tiga-fakultasfavorit-di-universitas-indonesia accessed in December 27th 2018 at $8.34 \mathrm{am}$

Subqi, I. (2016). Pola Komunikasi Keagamaan dalam Membentuk Kepribadian Anak. INJECT (Interdisciplinary Journal of Communication), 1(2), 165-180.

Rasimin, R. (2018). Metodologi Penelitian: Pendekatan Praktis Kualitatif.

Srivatav, Ijirae Manoj \& Champadani Adarsh Sharmik Vidyamandir. (2016). Web Coontent Management. International Journal of Innovative Research in Advanced Engineering Issue 03, Volume 3, March 2016.

\section{Internet:}

https://www.ru.nl/publish/pages/798477/factsheet universitas indones ia.pd. //accessed in December 24th 2018 at $9.00 \mathrm{am}$ http://www.ui.ac.id/en/about-us.html accessed in December 23rd 2018 at $10.20 \mathrm{am}$ 
http://www.ui.ac.id/wp-

content/uploads/dlm_uploads/2017/03/RENSTRA- 2015.pdf accessed in December 24th 2018 at 9.14am

Webometrics.info.en http://id.dinus.ac.id/about/52/history-dinus 